\section{Divisões na Igreja: desafios para o ecumenismo hoje}

\author{
ELIAS WolfF ${ }^{*}$
}

RECIBIDO: 17-04-15 - APROBADO: 06-07-15

Resumo: $\mathrm{O}$ artigo faz uma análise da divisão dos cristãos, num resgate histórico e teológico dos fatos que a causaram, das motivaçóes e da dinâmica dos acontecimentos. Propóe uma releitura desses elementos como caminho para a superação do seu potencial divisionista para o presente e o futuro da Igreja. Conclui que o caminho para a superação da divisão dos cristãos exige um redimensionamento da identidade cristá e eclesial, a cura da memória e uma revisáo estrutural na organizaçáo da Igreja.

PalaVras chave: Igreja, divisão, diálogo, unidade.

PARA CITAR ESTE ARTÍCULO:

Wolff, Elias. "Divisões na Igreja: Desafios para o ecumenismo hoje." Theologica Xaveriana 180 (2015): 381-407. http://dx.doi.org/10.11144/javeriana.tx65-180.dideh
Divisiones en la Iglesia: desafíos para el ecumenismo hoy

Resumen: El artículo hace un análisis de la división de los cristianos, en un rescate histórico y teológico de los hechos que la causaron, de las motivaciones y de la dinámica de los acontecimientos. Propone una relectura de esos elementos como camino para la superación de su potencial divisionista para el presente y el futuro de la Iglesia. Concluye que el camino para la superación de la división de los cristianos exige un redimensionamiento de la identidad cristiana y eclesial, la cura de la memoria y una revisión estructural de la organización de la Iglesia.

Palabras clave: Iglesia, división, diálogo, unidad.

\section{Divisions in the Church: Today's Challenges for Ecumenism}

Aвstract: This article examines the divisions among Christians by retrieving the motivations and dynamics of the historical and theological events that caused them. It proposes a rereading of such elements as a way to overcome their divisive potential for the present and the future of the Church. The text concludes that overcoming the divisions among Christians requires an evaluation of the Christian and ecclesial identity, healing the memory and performing a structural review or the Church's organization.

KeY wORDs: Church, division, dialogue, unity.

*O presente artigo é resultado parcial do projeto de pesquisa "O movimento ecumênico brasileiro, do ano 2000 a 2015”, ainda em desenvolvimento pelo autor no Programa de Pós-Graduação em Teologia, da Pontifícia Universidade Católica do Paraná, PUCPR (Brasil).

** Doutor em Teologia, Pontifícia Universidade Gregoriana, Roma. Atualmente é coordenador da Comissão Teológica do Conselho Nacional de Igrejas Cristãs do Brasil, coordenador do Núcleo Ecumênico e Inter-religioso da PUCPR, e membro do Programa de Pós-Gradução em Teologia da PUCPR. Correio eletrônico: elias.wolff@pucpr.br 


\section{Introdução}

Cerca de 2 bilhóes de pessoas ao redor do mundo professam a fé em Jesus Cristo, acreditam no seu Evangelho, vivem em comunidades que se entendem uma concretizaçáo da Igreja que Cristo quer neste mundo, e buscam orientar a sua vida no horizonte do Reino de Deus. Mas há um drama no mundo cristáo que todos sentem: a divisão nas formas de compreender e viver os ensinamentos do Evangelho. Muitas dessas formas surgem e se fortalecem num espírito de proselitismo e concorrência, com pouco, ou nenhum, espaço para a convivência e a interação das diferenças, o amor e a comunhão. A divisão cristã é uma realidade dramática.

No momento em que cristãos católicos romanos celebram os 50 anos do Concílio Vaticano II e cristãos luteranos se preparam para a comemoração dos 500 anos da Reforma de Lutero, é importante fazer uma releitura desses eventos perguntando-se pelo significado que podem ter para o cristianismo como um todo. Por muito tempo os católicos entenderam a Reforma apenas como divisão na Igreja do Ocidente. Mas é preciso verificar se essa leitura é possível ainda hoje como a única, e em que medida a Reforma apresenta também novas expressóes da fidelidade ao Evangelho e de compreensão da Igreja que tenha plausibilidade de acolhida por todos os cristãos do nosso tempo.

É preciso verificar, igualmente, se as intuições de reforma na Igreja apresentadas pelo Vaticano II dizem respeito apenas ao catolicismo romano ou podem ter implicaçóes também no conjunto dos cristãos batizados contribuindo, assim, para a superação do atual estado de divisão dos cristãos. Este estudo é acompanhado por uma questão prospectiva: é possível ter um novo olhar sobre as causas da separação que vá além do julgamento e da condenação dos fatos e de seus sujeitos, possibilitando uma nova compreensão em perspectiva ecumênica do atual pluralismo eclesial?

Não se trata de negar o passado e muito menos de abrir mão de convicções no presente. Isso trairia consequências negativas para a consciência das igrejas. O que se faz necessário é eliminar a perspectiva da controvérsia, ou seja, o confronto apologético polêmico, como eixo da relação entre as igrejas, e realizar um esforço intelectual crítico que tenha lucidez na análise da história das divisôes no universo cristão indagando, para além das disputas doutrinais, um modo de conceber a própria identidade cristã e eclesial não mais de forma irredutível, mas na perspectiva do diálogo, da compreensão e acolhida mútuas.

Para isso, faz-se mister uma releitura da história da divisão dos cristãos que, sem perder a objetividade na compreensão do que há de negativo nos elementos que a causaram e a expressam, aponte também para perspectivas, muitas vezes escondidas nesses mesmos elementos, que promovem a reconciliação. A motivação desse estudo é 
a fé que afirma que ali onde abunda o pecado, superabunda a graça $(\operatorname{Rm} 5,20)$, o que dá esperança para compreender que mesmo no terreno da divisão estão as sementes do perdão, da paz, da reconciliação e da comunhão. Cabe identificá-las, cultivá-las e fazê-las frutificar. A graça atua em lugares e de formas inusitadas.

Isso é o que propomos mostrar com este artigo, estimulado pelo relatório da Comissão Luterana-Católico-Romana para a Unidade, que propóe percorrer o caminho "Do conflito à comunhão", numa comemoração comum dos 500 anos da Reforma. Queremos, porém, integrar nessa caminhada os cristãos das diversas tradiçôes eclesiais que, cientes da gravidade da divisão na Igreja, se dispóe a percorrer os caminhos da reconciliação.

\section{O humano das divisões}

\section{Entre os mal entendidos e o não querer entender}

A história das divisōes na Igreja é marcada tanto por uma série de mal entendidos, quanto pela falta de disponibilidade para entender as razóes do outro. Houve radicalismos e absolutizaçóes de determinados elementos da fé cristá em detrimento de outros. O contexto de acusaçóes e hostilidades mútuas impediram perceber que as diferenças de posições nem sempre expressavam contradição, poderiam também oferecer enriquecimentos na compreensão e vivência do Evangelho.

No século V, nunca se soube o que realmente Nestório teria a dizer no Concílio de Éfeso, pois ele sequer foi ouvido na reunião dos bispos. Nas controvérsias do século XI, o jogo de poder entre Roma e Constantinopla provocou um diálogo de surdos. No início dos conflitos com os protestantes no século XVI, as autoridades romanas não se dispuseram a ouvir Lutero - e os bispos de sua regiáo só o fizeram após o agravamento do conflito, agora, porém, com a influência de muitos fatores não propriamente teológicos.

Nessas situaçóes conflitivas, mais que diálogo, houve encontros para debates, já destinados a fazer com que o crítico à Igreja oficial se retratasse e retirasse seus posicionamentos antes mesmo de fazer-se compreender. O caso de Lutero é paradigmático. Certamente, nem tudo o que ele pensava sobre a penitência, o sacerdócio comum, o vínculo entre Evangelho e fé, as estruturas eclesiais, entre outros, era contra a Igreja estabelecida. Apontava para contradiçóes nela existentes. Mas qualquer crítica ao status quo era facilmente vinculada com as vozes heréticas já silenciadas como Wyclif, João Huss, Savonarola e outros.

Lutero surge num momento em que Roma estava saindo do V Concílio de Latrâo (1512-1517), pensando ter resolvido as questôes doutrinais de então. O Papado 
da época não tinha ainda se restabelecido completamente do cisma de 1378 a 1417 , do Concílio cismático de Pisa (1511-1512), e O Império de Carlos V cuidava do Estado Pontifício, influenciando em decisões curiais. Entra em jogo também o modo de Lutero expor suas idéias, sem usar meios termos para referir-se à Igreja instituída denominando o papa como "Anticristo" e queimando a bula papal que o excomungava. ${ }^{1}$ O clima de animosidade que dificultava o diálogo é bem expresso nas palavras de Zaccaria Delfino, núncio pontifício junto à corte imperial, ao escrever, em 1559, ao cardeal Carlo Carafa, sobrinho de Pio IV, sobre as discussóes no Concílio de Trento:

E Deus quis que aquele herético espírito de buscar acordo entre os católicos e os heréticos não reinasse, e hoje não reinasse em muitos, pois daqui vejo que nasceu todo o fundamento do mal do qual hoje a república cristã padece, e pior são os que estão em seu meio, mais danosos do que os mediadores da concórdia, que não são os claramente heréticos. ${ }^{2}$

Demorou muito tempo para que houvesse o entendimento que os posicionamentos teológicos diferentes nem sempre se contradizem e, portanto, não justificam, de per si, as rupturas corridas na Igreja. Na 96a. Congregação Geral do Concílio Vaticano II, mons. Maximus Hermaniuk, metropolita ucraniano de Winnipeg, no Canadá, apresentando ao plenário a primeira parte do Cap. III do esquema De oecumenismo, afirmou:

O Oriente e o Ocidente não diferem senão na diversa expressão da mesma verdade dogmática, da mesma praxe litúrgica e de uma semelhante disciplina eclesiástica. [...] naquele longínquo ano de 1054, o Legado Pontifício Cardeal Humbertus, quase três meses depois da morte de Leáo IX, na sua famosa excomunhão contra o Patriarca Cerulário e seus seguidores, atribuiu-lhes gratuitamente todas as heresias então conhecidas na Igreja e por causa destas heresias gratuitamente imputadas, os condenou a todos, muito embora, como consta hoje da história, em toda esta luta não se tivesse duvidado de nenhuma verdade dogmática. ${ }^{3}$

Sobre as divisões do século XVI, constata-se hoje com mais serenidade que “o juízo dos reformadores nos confrontos da Igreja Católica romana e a teologia do

\footnotetext{
${ }^{1}$ Lutero, no final de sua vida, chegou a negar à tradição católica romana "ser Igreja” de forma brusca: "Não lhes reconhecemos serem eles Igreja; e eles táo pouco o são; mas eles não querem ouvir; a coisa inaudita que sob o nome de Igreja eles mandam e desmandam; pois mesmo uma criança de sete anos, graças a Deus, sabe o que a Igreja é." (Lutero, "Artigos de Esmalcalde - A Igreja”, 363).

${ }^{2}$ Ruggieri (org.), Alle radici della divisione - Una rilettura dei grandi scismi storici, 31.

${ }^{3}$ Kloppenburg, Concílio Vaticano II, Vol. IV, Terceira Sessão, 438.
} 
seu tempo com freqüência não eram livres de deformações polêmicas, que em parte prolongam os seus efeitos até o presente". ${ }^{4} \mathrm{Da}$ parte da Igreja Católica, há também o reconhecimento de faltas que podem ter causado ou intensificado as tensões que levaram a divisões: "Por isso, pedimos humildemente perdão a Deus e aos irmãos separados." (UR 7).

\section{Entre religião e política}

As razões decisivas para o rompimento da comunhão extrapolam as motivações religiosas e agregam elementos de caráter cultural e político que, não poucas vezes, se sobrepóe aos propriamente teológicos. Nas querelas entre Egito e Síria, no século IV, por exemplo, estava em jogo o conflito entre as grandes sedes patriarcais. Alexandria lutava ao mesmo tempo contra Antioquia e contra Constantinopla. Antioquia era metrópole da Síria e das regiốes que falavam siríaco, herdeiras da cultura semítica. Alexandria era metrópole do Egito e dos povos que falavam copto.

Nessas regióes o povo simples falava a língua tradicional e a elite falava grego. Isso configurava as lutas contra a Igreja de Constantinopla como uma luta contra a elite grega, a dominaçáo do império romano que falava o grego de Constantinopla.

$\mathrm{Na}$ divisão entre Oriente e Ocidente no século XI, também pesou o jogo político entre os patriarcados. Constantinopla considerava-se em igualdade de direito com Roma no governo do império, confirmado no Concílio de Calcedônia mesmo sob os protestos, em vão, do papa Leão I. Com a ocupaçáo de Roma pelos povos germânicos (476) e o desaparecimento do Império, o papa em Roma tornou-se o principal líder do Ocidente, inclusive comandando exércitos contra os invasores e coroando imperadores, como Carlos Magno (800) e mais tarde seu filho Luís (816) e, inclusive, seu neto Lotário (823).

O fato de o papa "fazer" imperadores provoca revolta em Constantinopla. Julgando-se a máxima autoridade, no século XI Roma acrescenta, de forma unilateral e arbitrária, o filioque ${ }^{5}$ ao Símbolo de fé do século IV (o credo nicenoconstantinopolitano). É então que os orientais acusam a Igreja do Ocidente de herética

\footnotetext{
${ }^{4}$ Comissão Internacional Católica-Luterana, "L'unità davanti a noi” No. 52, 777.

${ }^{5} \mathrm{O}$ símbolo de fé aprovado pelos concílios de Nicéia e de Constantinopla dizia: "Creio no Espírito Santo, que procede do Pai..." Na Espanha, começou-se a rezar "procede do Pai 'e do Filho" (filioque) e no terceiro Concílio de Toledo (589) essa cláusula foi incluída no símbolo. Esse uso se alastra com Carlos Magno e os francos, sendo rezado, inclusive, pelos monges francos em Jerusalém. A Igreja de Constantinopla sempre rejeitou esse acréscimo à fórmula original do Credo.
} 
e se auto-denominam os únicos "ortodoxos". As querelas e anátemas que se seguem entre Oriente e Ocidente, até a separação definitiva em 1054, são conseqüências também desse jogo de poder político e religioso.

Também as divisões do século XVI sofreram influências políticas consideráveis. $\mathrm{Na}$ dieta de Wormns (1521) revelaram-se as forças políticas a favor de Lutero. Em seguida, os influentes da política na Alemanha dividiram-se em dois blocos, católico e evangélico. A Reforma entra nos territórios individuais e com a Liga de Esmalcalda (1531) associa-se definitivamente a forças políticas que a sustentam. Como consequência, aconteceu o confronto entre o imperador e as províncias alemás, bem como outras potências européias. Igualmente com Calvino e Henrique VIII, o vínculo entre religião e política é explícito tanto em Genebra quanto na Inglaterra.

\section{Tensões na inculturação do Evangelho}

As divisões na Igreja têm a ver também com o modo como cada regiáo entendeu e viveu o Evangelho. Após afastar-se da matriz cultural do judaísmo, o cristianismo penetra na cultura grega, latina, germânica, anglo-saxônica, céltica, formando novos estilos de vida e paradigmas culturais para regióes inteiras. Esses estilos e paradigmas entram em conflito em determinados momentos da história.

$\mathrm{Na}$ ruptura dos nestorianos e monofisitas nos séculos IV e V, manifestaram-se as diferenças das culturas grega e oriental na compreensão do dogma cristológico. No distanciamento progressivo entre Ocidente e Oriente no século XI, influenciaram questôes teológicas como o Filioque, o uso de pães ázimos na celebração eucarística, o purgatório, a epíclese na consagração eucarística, e também questóes culturais e disciplinares como o celibato dos padres e o uso da barba, expressando as diferenças de mentalidade entre gregos e latinos.

Na divisão do século XVI, os debates sobre temas doutrinais como a justificação, os meios da graça, a hierarquia, se deram no contexto cultural da modernidade, marcada pelo pensamento humanista. O espírito humanista, aberto às diferentes expressóes culturais, criou o clima para que os reformadores elaborassem suas críticas aos métodos inquisitoriais da Igreja e ao bispo de Roma. Constatando a contradição entre a simplicidade dos evangelhos e as complicadas argumentaçóes teológicas, a vida das primeiras comunidades e as estruturas da Igreja, eles passaram a almejar uma reforma do cristianismo - clamor há muito existente na Igreja.

As diferenças entre os humanistas e os reformadores é notória. Os primeiros afirmam a centralidade do ser humano; e os segundos centram-se no primado da revelação da graça de Deus. Mas o humanismo criou um ambiente cultural favorável para o desenvolvimento dos princípios reformistas religiosos. Pessoas como Giovanni 
Pico della Mirandola (1463-1494), Thomas Morus (1478-1535), Erasmo de Roterdã (1466-1536), mesmo católicos, desenvolveram um pensamento humanista com fortes críticas à Igreja, embora não concordassem com as atitudes radicais reformistas que levaram à ruptura.

\section{A gravidade teológica das divisões \\ O pecado}

Qual a causa mais profunda da divisão na Igreja? Na raiz de todas as causas está o pecado, que se expressa pelo orgulho e a vontade humana em desarmonia com a ação da graça. A divisão é, em última instância, expressão do pecado. Como os coraçóes humanos têm dificuldades para se deixarem possuir plenamente pelo Espírito, e muitos mesmo possuindo "as primícias do Espírito" ( $\mathrm{Rm} 8,23)$, são ainda governados pela obstinação, a fidelidade ao Evangelho da comunhão e abertura para a graça da unidade não é plena.

Por isso a forma histórica e manifestação exterior da Igreja não é ainda adequada à sua verdadeira natureza. $\mathrm{Na}$ Igreja como sociedade histórica não opera apenas o poder do Espírito. Mesmo os que possuem o Espírito e por isso sáo unidos a Cristo, têm também a realidade negativa do egoísmo, do orgulho, da falta de caridade e de fé.

É porque a Igreja é uma fraternidade em Cristo que a divisão é um pecado. Para superar esse pecado, o caminho é a conversão (UR 8). Essa exige a consciência de sermos

...todos igualmente culpados; até que cada partido na nossa Igreja não sente a aguilhoada da culpa, até que cada um de nós não experimenta o embaraço quando é obrigado a identificar-se com o seu partido, não pode haver nenhum crescimento substancial rumo à unidade cristã. ${ }^{6}$

Por isso, não se recompóe a unidade da igreja com simples reagrupamento de pessoas, doutrinas, instituições. A unidade não é algo mecânico, que acontece como consequência lógica do ajustamento de realidades externas. É preciso começar a partir do Espírito que atua no interior de cada fiel e da igreja e, como consequência, os elementos exteriores estarão em comunhão.

${ }^{6}$ Fé e Constituição, “I Conferência Mundial - Lausanna, 1927” No. 688, VI, No. 322. 


\section{Culpa de ambos os lados}

A verdade é que houve culpa de ambos os lados. Os extremismos, radicalismos e exclusivismos não foram de uma parte apenas. $\mathrm{O}$ atual diálogo entre as igrejas possibilita essa consciência: "Reconhecemo-nos culpados do fato que estas diferenças tenham dividido as nossas igrejas e que a divisão tenha ofuscado o nosso testemunho do Cristo, causando dor aos homens e aos povos."

Reconhecer a culpa é, de um lado, um ato de humildade que evita colocar-se na postura de posse da verdade frente ao outro e de julgá-lo como o único no erro. De outro lado, a humildade leva a aprender com os erros, próprios e dos outros:

Não queremos julgar-nos uns aos outros $(\mathrm{Rm} 14,13)$. Mas queremos reconhecer juntos a nossa culpa. Isto vale também para a graça da unidade: 'Todos pecaram' $(\mathrm{Rm} 3,23)$. Precisamos ver e dizer isso com toda seriedade e daí tirar as conseqüências para nós. ${ }^{8}$

Naturalmente, é de se crer que nem sempre os fatores causadores da divisão são intencionais, muitos são movidos por um verdadeiro amor à Igreja e ao Evangelho. Contudo,

Mesmo se fizemos o que julgamos ter sido justo, devemos recordar que somos culpáveis no pecado não cometido inteiramente por nós e que não podemos dissociar-nos do pecado da divisão. A confissão da unidade com Cristo exige necessariamente a confissão da nossa solidariedade com os nossos irmãos no pecado. ${ }^{9}$

\section{Contradição, escândalo, obstáculo}

O Concílio Vaticano II entende a divisão dos cristãos como "contradição", "escândalo" e "obstáculo" (UR 1). São três termos que expressam a gravidade da situação de desentendimentos e da falta de comunhão entre os cristãos:

1. É contradição ao projeto de Deus pai de formar de todos os povos um só (Ez 37,16-28; Jo 11,51-52; Rm 10,12; Gl 3,8; Ef 2,14.16; Ap 7,9). Projeto que se expressa na ação de Cristo e seu desejo que todos os seus discípulos "sejam

\footnotetext{
${ }^{7}$ Comissão Internacional Católica-Luterana, “Tutti sotto uno stesso Cristo” No. 4.

${ }^{8}$ João Paulo II, “Discurso em visita na Alemanha, em 1980”, citado pela Comissão Internacional CatólicaLuterana, "L'unità davanti a noi" No. 51.

${ }^{9}$ Conselho Mundial de Igrejas, "Assemblea di Evaston (1954) - Rapporti delle sezioni” No. 98.
} 
um" (Jo 17,21), e vivam "no mesmo Espírito" de Cristo (1Cor 1,10), que a todos reúne numa só esperança e uma só fé (Ef 1,4-6).

2. É escândalo para o mundo porque os cristãos deixam de dar um testemunho convincente do Deus no qual crêem e que o mundo espera. Frustram as esperanças que o mundo tem de unidade e de paz.

3. É um obstáculo, em dois âmbitos: internamente, porque impede a comunidade eclesial de viver na caridade; externamente, porque dificulta a pregaçáo do evangelho do amor e da paz no mundo.

"Contradição", "escândalo" e "obstáculo", tal é a realidade dramática da divisão dos cristãos e da Igreja. "A história não atesta algum escândalo maior do que essa fratura da fraternidade na Igreja de Cristo." ${ }^{10}$ Náo se pode entender isso como algo normal da vida cristá e eclesial. Não se pode manter o statu quo de separação dos cristáos e de poucas relações amigáveis como se fossem naturais, normais e condizentes com o ser da Igreja. Trata-se de uma anomalia eclesial, que expressa a divisão e a agrava.

\section{Tentativas de re-interpretação das divisões}

Não se pode mudar a história das divisóes ocorridas no passado. Mas é necessário reler hoje os fatos e as intençôes dos seus sujeitos num novo esforço de compreensão e de busca de superação das suas consequências negativas. É preciso verificar, de um lado, em que medida essas intençóes realmente ferem e extrapolam a ortodoxia da fé; e, de outro lado, em que medida seus autores, ao menos em suas intuiçóes originais, propunham uma nova e legítima compreensão da fé cristã e da Igreja. E se acaso assim foi, então por que levaram à divisão? Um modo coerente de compreender e afirmar o Evangelho não deveria fragmentar a Igreja, pois as divisōes "não são expressões de uma legítima multiformidade na unidade, mas divisóes da unidade numa multiplicidade contraditória”. ${ }^{11}$

A divisão dos cristáos vai além das divergências sobre determinados elementos da doutrina cristá. Ser católico romano, ortodoxo, protestante, anglicano, pentecostal, diz respeito ao modo de entender e viver o conjunto das verdades do Evangelho. A divergência está no modo de conceber esse conjunto. Esses modos aos poucos se transformam em diferenças também de conteúdo e constituem uma tradição, uma

\footnotetext{
${ }^{10}$ Fé e Constituição, "I Conferenza Mondiale: Losanna, 1927” No. 687.

${ }^{11}$ Kasper, Chiesa Cattolica - Essenza, realtà, missione, 255.
} 
confissão, uma nova identidade religiosa. E o diálogo torna-se difícil quando se é habituado apenas ao próprio modo de entender e viver a fé, ignorando a tradição dos outros e conservando opiniōes que muitas vezes deturpam a sua verdadeira posição. ${ }^{12}$

Para se obter uma melhor acolhida entre as igrejas no presente e uma plena comunhão futura, a história da divisão deve ser revista num espírito de diálogo e conversão que contribua para a superação de suas causas. Para isso é fundamental uma nova consciência do passado, compreendendo a história da Igreja de modo que todas as tradiçôes cristâs possam nela se reconhecer.

O fato de compreender de modo diferente os acontecimentos complexos da história passada, como as diferenças que persistem nas questóes centrais da nossa fé, não deve dividir-nos para sempre. Nem mesmo as recordaçóes dos acontecimentos do passado deve limitar a liberdade dos esforços atuais para reparar os desastres provocados por tais acontecimentos. ${ }^{13}$

\section{Para além do humano}

Acima do pecado da divisão, existe a graça de Deus. Assim como o pecado não cancela definitivamente a graça na vida do fiel, também não cancela definitivamente a unidade na Igreja de Cristo, pois ela é uma "divina vocação" e uma "graça” (UR 1), dada pelo próprio Senhor. É a graça que leva cada igreja a enfrentar o problema da divisão como uma responsabilidade própria e comum ao mesmo tempo. Ela permite às igrejas descobrirem sob as diferenças um acordo que as une e as impede de viverem separadas em tudo, mesmo se ainda não se acolhem mutuamente de forma plena:

...a mesma intensidade das nossas divergências testemunham uma convicçáa comum que vem d'Ele: o corpo de Cristo é uma unidade que nos proíbe seja de nos ignorarmos mutuamente, seja de nos conformarmos com um acordo apenas sobre alguns aspectos da fé, deixando outros não reconciliados. ${ }^{14}$

A divisão é um drama espiritual dos cristãos. Expressa o pecado que se manifesta pelas contradiçôes, incompreensóes, falta de caridade. A questão "por que Deus permite a divisão?", é equivalente à questão "por que Deus permite o pecado?”. Não há outra resposta a não ser por amor, um amor que nos deixa livres, inclusive para negá-lo. Mas

\footnotetext{
${ }^{12}$ Conselho Mundial de Igrejas, "Assemblea di Amsterdam - 1948 - Rapporti delle sezioni” No. 6.

${ }^{13}$ João Paulo II, João Paulo II, "Discurso à Federação das Igrejas protestantes da Suíça (junho de 1984)", Vatican, http://w2.vatican.va/content/john-paul-ii/it/speeches/1984/june/documents/hf_jpii_spe_19840614_chiese-protestanti.html (acesso em 20 de julho de 2014).

${ }^{14}$ Conselho Mundial de Igrejas, “Assemblea di Amsterdam - 1948 - Rapporti delle sezioni”, No. 10.
} 
como Deus não nos abandona nas situaçôes de pecado, também não está ausente das circunstâncias que dividem a sua Igreja, superando-as com a sua graça:

Deus pode tirar o bem até mesmo das situações que ofendem o seu desígnio, podemos entáo descobrir que o Espírito fez com que as oposiçóes servissem, em algumas circunstâncias, para explicitar aspectos da vocação cristã, como sucede na vida dos santos. Apesar da divisão, que é um mal de que nos devemos curar, todavia realizou-se como que uma comunicação da riqueza da graça, que está destinada a embelezar a koinonia: a graça de Deus estará com todos aqueles que, seguindo o exemplo dos santos, se esforçam por favorecer as suas exigencias. (UUS 85).

Portanto, há um mistério na realidade da divisão da Igreja que nos leva a pensar que "as divisôes são sim obras do homem, mas são também permitidas por Deus. Nelas se verifica uma divisão dos espíritos, mediante a qual deve vir à luz a fidelidade dos cristãos. Elas são provas escatológicas". ${ }^{15} \mathrm{Na}$ perspectiva da fé que nos permite discernir a presença da graça mesmo em situaçóes de desgraça,

Pode-se descobrir a mão de Deus no nosso cisma, qualquer que seja a nossa falta. A diversidade das igrejas é uma admoestaçáo constante relativamente a nós para que respeitemos a diversidade dos dons do Espírito [...]. A história da salvação avança, apesar de nossas imperfeiçóes e dos nossos pecados. ${ }^{16}$

\section{Motivações de fé}

Um dado é fato: as controvérsias teológicas tem originalmente a intenção de confessar a fé cristã e prestar um serviço à Igreja, não buscam a divisão. Assim foi, por exemplo, com as separaçóes ocorridas no século $\mathrm{V}$, por motivaçóes de fé cristológicas; aquela do século XI, com base na fé trinitária; as ordens mendicantes clamaram por reformas na Igreja medieval por amor e fé à Igreja; e os reformadores protestantes do século XVI entendem-se fundamentados na fé na justificação unicamente em Cristo.

Ancorados na própria compreensão da fé, alguns julgaram que outros se distanciaram da estrutura eclesial e da fé que Deus deu à Igreja por pretensóes injustificáveis e doutrinas infundadas; outros sentiram-se chamados por Deus para uma reforma da fé e da constituição da Igreja, entendendo que para isso precisariam deixar

\footnotetext{
${ }^{15}$ Kasper, Chiesa Cattolica, 255.

${ }^{16}$ Cullmann, "Conferência em São Luís dos Franceses, em dia 02 de dezembro, durante a 2a . sessão do concílio, falando sobre a "história da salvação no Novo Testamento", 345.
} 
as estruturas católicas romanas (igrejas da Reforma). Outros, ainda, julgaram que a fé deveria ser reformada no interior mesmo do episcopado histórico (Igreja Anglicana e antigos católicos). E houve também quem julgou que as igrejas oficialmente constituídas não permitiam uma autêntica proclamação da palavra de salvação (igrejas livres e metodistas). Em tudo isso, "iniciativas de consciente obediência à vontade de Deus produziram, sem querer, fraturas na comunhão cristã no nível de doutrina, sacramentos, constituiçôes". ${ }^{17}$

O diálogo conclui hoje que "seria trágico se os nossos reformadores do século XVI tivessem desejado fundar uma nova igreja e separar-se da Igreja Católica. Mas não foi assim”. ${ }^{18}$ Para superar as divisóes, Calvino diz a Cranmer em 1552: “... nada me deteria, e atravessaria, se fosse necessário, dez mares." E Melanchthon escreve a Campeggio a respeito da primeira versão da "doutrina protestante" apresentada ao Imperador em Augsburgo (1530):

Não temos nenhuma doutrina de fé, divergente da Igreja Romana. Até a data de hoje, reverenciamos o papado. Até o último suspiro seremos fiéis a Cristo e à Igreja de Roma, ainda quando condenados pela Igreja, ainda que só pequenas discrepâncias de ritos pareçam conturbar a concórdia. ${ }^{19}$

O cardeal J. Willebrands assim se expressou na quinta assembléia da Federação Luterana Mundial:

Quem [...] poderia negar que Martinho Lutero fosse uma pessoa profundamente religiosa, que lutou com honestidade e dedicação pela mensagem do Evangelho? Quem poderia negar que, não obstante o fato de ter lutado contra a Igreja Católica romana e a sede apostólica (e por amor da verdade, não podemos calar estes fatos), preservou uma porção preciosa da fé católica tradicional? Não é, talvez, verdade também que o Concílio Vaticano II respondeu a exigências que, entre outras, foram expressadas por Martinho Lutero, e que consentem atualmente uma melhor expressão de vários aspectos da fé e da vida cristâ? Poder reafirmar tudo isso, não obstante todas as diferenças, é motivo de grande alegria e esperança. ${ }^{20}$

A questão a responder é: qual a possibilidade de reconhecer legítimas inspiraçôes de fé nas pessoas diretamente envolvidas nas circunstâncias das divisóes? Qual o nível

\footnotetext{
${ }^{17}$ Conselho Mundial de Igrejas, “Assemblea di Evaston (1954) - Rapporti delle sezioni” No. 16.

${ }^{18}$ Fé e Constituição, “I Conferenza Mondiale - Losanna, 1927”, No. 19.

${ }^{19}$ Tuchle, Nova história da Igreja - A Reforma e Contra-Reforma, III, 79.

${ }^{20}$ Comissão Internacional Católica-Luterana, "Martin Lutero, Testimone di Gesù Cristo” No. 23.
} 
de verdade e de erro que se manifesta em seus posicionamentos? Todas expressam a convicção de que não se pode transigir com a verdade. E, bem intencionadas, entendem que a sua verdade está em sintonia com a verdade que se origina em Deus, nos evangelhos. Mas a dificuldade de apresentar provas de uma missão recebida do "alto" faz com que justamente essa "verdade" é o que os outros tenham dificuldade para compreender.

Está em questão o que se entende por ortodoxia da fé. Há sim divergências doutrinais na raiz da divisão dos cristãos. Mas o que queremos mostrar aqui é que havia em seus autores a convicçáo de agirem na verdade da própria consciência e, na compreensão deles, essa convicção não traía a verdade da Igreja. Assim, uma releitura dos reformadores permite concluir:

Reconheçamos, por exemplo, que no início os reformadores não quiseram agir contra a unidade da Igreja, mas queriam simplesmente sublinhar certos pontos de doutrina que lhes pareciam obscuros [...]. Muitas vezes rejeitamos como inteiramente falsas afirmaçóes que continham boa parte de verdade [...]. Temos considerado a revelação divina excessivamente como uma possessão passiva [...]. Demasiadas vezes confundimos a unidade com a uniformidade de rito ou de teologia [....]. Nossos irmãos cristãos têm o direito que lhes respeitemos as diferenças legítimas. ${ }^{21}$

Mesmo nos novos grupos cristãos pentecostais do século XX e XXI, que expressam a contínua fragmentação do cristianismo, é possível constatar a fé numa ação renovadora do Espírito. Pode-se questionar muitos elementos acerca da compreensão, vivência e expressão da fé pentecostal. Mas essa fé como tal é o que se constata como razão de ser dos membros das comunidades pentecostais.

\section{Ecclesia semper reformanda}

Uma aspiração histórica. A aspiração por reformas na Igreja é uma constante histórica. É o que se constata nos concílios dos primeiros séculos, no monaquismo, nas ordens mendicantes, nos pontificados de Gregório I (590-604) e Gregório VII (1073-1085), em místicos medievais como Matilde de Magdeburgo (1207/1210-1282/1294), Mestre Eckhart (1260?-1327), Catarina de Sena (1260-1328).

Muitos sofreram perseguiçóes e mortes (albigenses, cátaros, valdenses); outros foram absorvidos pela instituição eclesial (franciscanos, dominicanos, servitas, carme- 
litas). Esta exigência ganhou espaço nos concílios de Constança (1414-1418) e Basiléia (1431-1437) que propuseram uma reforma in capite et in membris, in fide et in moribus. Mas o fracasso na recepção desses concílios levou à perda de uma oportunidade ímpar de realizar mudanças estruturais na Igreja.

No século XVI, Lutero dá voz a esse clamor. Questionava se a Igreja, na forma visível de então, poderia ser, de fato, mediadora entre Cristo e o fiel, propondo uma eclesiologia mais horizontal da comunidade que valorizasse o sacerdócio comum dos fiéis. A doutrina das "duas espadas" é contestada pela distinção dos dois reinos, e o ar triunfal da instituiçáo e da hierarquia pela doutrina sobre a cruz.

O Concílio de Trento se propôs, em seu primeiro momento (1546-1547), como um concílio reformador. Projetou uma Igreja mais espiritual, um cristianismo menos ritualista e menos jurídico. Falava de "decretos dogmáticos" e "decretos de reforma". Mas a apologia contra Lutero levou a uma "contra-reforma", institucionalizando e disciplinando a fé, o contrário do que Lutero propunha.

Também o Concílio Vaticano I pretendia desenvolver uma compreensão da Igreja sob a noção de corpo de Cristo. Essa noção está presente na primeira redação do Schema constitutionis dogmaticae de Ecclesia Christi do Vaticano I, especialmente no primeiro capítulo. Mas foi superada pela a eclesiologia da sociedade perfeita na redação de J. Kleutgen, e levada ao grau máximo com a definição dogmática sobre o ministério petrino na Pastor aeternus. ${ }^{22}$

Que encontra eco nos séculos XIX e XX. É apenas a partir do século XIX que surgem reais possibilidades de redimensionamento no pensamento teológico católico romano podendo, entáo, incidir na eclesiologia. Contribuiu para isso a cultura do romantismo no século XIX, com o acento no elemento vital, na historicidade, na espiritualidade bíblica e patrística, e na experiência vivida da Igreja. ${ }^{23}$

No século XX, o esforço por renovação eclesiológica fortalece a compreensão da Igreja como "mistério", "sacramento" e, sobretudo, "povo de Deus". ${ }^{24}$ Essa renovação foi

\footnotetext{
${ }_{22}$ Para aprofundar a questão, ver: AnTón, El misterio de la Iglesia, Vol. 2, 344-355.

${ }^{23}$ Möhler, L 'Unità nella Chiesa. Il principio del cattolicesimo nello spirito dei Padri della Chiesa dei primi tre secoli. Outro teólogo importante nesta direção foi J. H. Newman (1801-1890). Cfr. Bouyer, Newman. His Life and Spirituality.

${ }^{24} \mathrm{Um}$ dos primeiros sistematizadores da concepção de Igreja como povo de Deus, foi Vonier, The People of God, enriquecida depois, entre outros, por De Lubac, Catholicisme. Les aspesctes sociaus du dogme; Congar, Chétiens désunis; Idem, Esquisses du mystère de l'Église.
} 
influenciada pelos movimentos bíblico, patrístico e litúrgico, impulsionados pelo novo pensar da fé de teólogos como H. De Lubac, Y. Congar, H. U. Von Balthasar, K. Ranner, o Cardeal Suenens, entre outros.

O contexto cultural, marcado pelo pensamento filosófico da fenomenologia e do existencialismo, ajudam a teologia a abandonar uma visão essencialista da realidade, superar posições absolutistas da verdade e entendê-la como processo, o que implica em relação, diálogo, intercâmbio de experiências e de saberes. No Ocidente, a sociedade secularizada afirma a autonomia entre religiáo e Estado e o pluralismo cultural torna-se berço do pluralismo religioso, com reivindicação da liberdade religiosa. $\mathrm{O}$ movimento ecumênico, de origem protestante, se fortalece com encontros realizados às vésperas e durante o concílio Vaticano II, eventos que repercutiram de algum modo na reflexão dos padres conciliares.

Assumida no Concílio Vaticano II. Nesse contexto, acontece o Concílio Vaticano II (1962-1965), assumindo magisterialmente a aspiração por reforma na Igreja (LG 8; UR 6), no programa de aggiornamento proposto pelo papa João XXIII. "Reforma" tem aqui o significado de mudança na forma, uma mudança na continuidade, como atualização do conteúdo de sempre da fé católica ${ }^{25}$.

Superando o dogmatismo fixista da escolástica, o Vaticano II fundamenta seu ensino doutrinal numa perspectiva mais bíblica, litúrgica, missionária, histórica e ecumênica. Há distinção entre o conteúdo da fé e sua expressão (João XXIII, Discurso inaugural); distinguem-se, igualmente, as verdades da fé, que mesmo estando vinculadas umas às outras possuem entre elas uma ordem ou hierarquia (UR 11).

A consequência é um redimensionamento do enfoque eclesiológico que dá prioridade ao mistério (LG 2-5), objeto de fé, Deus uno e trino presente na Igreja (LG 2-4). A Igreja aparece, então, como sacramento de salvação (LG 1,9,48,59; SC 5,26 GS 42,45; AG 1,5), com uma nova compreensão do conceito de comunhão (LG 4,8,13-16,18,21,24; DV 10. GS 32; UR 2-4,14, 17-19,22): com Deus pela Palavra, os sacramentos e o culto litúrgico (DV, SC); com todos os cristáos pela busca da unidade plena (LG 15; UR); com toda a humanidade pelo respeito, o diálogo e a cooperação entre os povos (GS) e as religióes (NA; DH).

\footnotetext{
${ }^{25}$ Essa questão provoca acalorados debates na hermenêutica do Concílio Vaticano II, para entender o que a sua proposta de reforma que implica em mudanças e até mesmo abandono de elementos considerados não apropriados para a compreensão da fé cristã e da igreja em nossos tempos, e o que é reforma na conservação de elementos que expressam a fé de sempre.
} 
As propostas de reforma no Vaticano II acontecem:

1. No nivel institucional, afirmando a colegialidade episcopal e valorizando as igrejas locais. O papa Paulo VI realizou depois uma séria reforma da cúria romana, com a finalidade de propor maior participação nas decisóes magisteriais.

2. No nivel pastoral, o Vaticano II possibilitou um pluralismo de modelos pastorais, buscando superar o uniformismo na evangelização; fez a opção pela postura de misericórdia no lugar da severidade e da condenação, pela qual a Igreja não se entende julgadora do mundo, das pessoas, de outras igrejas e religióes, mas humilde companheira de caminhada na busca da verdade. ${ }^{26}$

3. No nivel teológico-doutrinal, as reformas sustentam as mudanças ocorridas nos níveis anteriores. Aqui constatamos uma nova forma mentis na fé católica, que se caracteriza por uma atitude, entre outras, de humildade na compreensão da verdade. A Igreja Católica Romana entende que não esgota em suas estruturas a Igreja de Cristo (LG 8; UUS 13), pois a verdade do Evangelho e da fé cristã está presente também em outras igrejas (UR 3.15; LG 8; LG 15).

Assim, as reformas, no sentido de renovação e atualização são, ao menos em princípio, desejadas e buscadas pelo Concílio Vaticano II (LG 8; UR 6). Na verdade, trata-se de uma necessidade da própria Igreja, para ser mais fiel à sua identidade, natureza e missão.

\section{Convergências nas aspirações por reforma}

Salvas as devidas diferenças do que se entende por "reforma” bem como os diferentes contextos das propostas reformistas ao longo da história, podem ser verificadas sintonias entre as intuiçôes de fundo da Reforma protestante e a eclesiologia católica no contexto moderno e contemporâneo.

Congar considera que tanto J.A. Möhler, quanto J.H. Newman abordaram o mistério da Igreja pelo lado do "sujeito religioso" 27 , relacionando fé e razão, vida espiritual e intelectual, psicologia e dogma, profetismo e Igreja. Isso possibilita estabelecer algum vínculo desses teólogos com a "Igreja invisível” dos reformadores do século XVI, pelo fato de ambos valorizarem a dimensão da subjetividade, carismática e espiritual da fé.

\footnotetext{
${ }^{26}$ Alberigo, "Vaticano II e la riforma della chiesa", 101.

${ }^{27}$ Congar, Vrai et fausse réforme dans l'Église, 9.
} 
Os anos 50 do século XX não possibilitavam pensar em reforma no catolicismo de forma consequente. Vivia-se numa perspectiva triunfalista no ato de "apresentar o patrimônio católico romano, como algo de completo, de exaustivo, de profundamente e diretamente coerente com o Evangelho". ${ }^{28}$

Não obstante, havia preocupações, incertezas, fermentos de mudanças, como os movimentos litúrgico, bíblico, ecumênico. Dois fatos contribuem decisivamente para fazer do Vaticano II um concílio de reforma: o "Memorial de Constantini” redigido pelo Cardeal Constantini, missionário no Extremo Oriente, onde se encontra uma proposta de reforma na Igreja formulada na ocasião do conclave no qual foi eleito o papa Pio XII (1939), não considerado por esse mas recordado ao papa João XXII em sua eleição, em $1958^{29}$; e a proposta do aggiornamento apresentada por João XXIII, isto é, renovação, mudança na Igreja, o que inclui reformas.

Pelo menos em dois aspectos a proposta de reforma no Vaticano II converge com a aspiração luterana:

1. Fidelidade ao Evangelho, por uma renovação profunda da Igreja, sob a guia do Espírito Santo. Trata-se de um modo de conceber a Igreja à luz da Palavra de Deus, com densidade do mistério evangélico. Destacam-se aqui as constituiçôes Dei Verbum, na qual a Igreja se entende obediente e servidora da Palavra de Deus; Sacrosanctum Concilium com reformas no culto de louvor a Deus, tendo a Eucaristia como "ápice e fonte da Igreja"; e Lumen gentium, com a categoria bíblica de Igreja Povo de Deus.

2. Fidelidade à história humana, pela qual o Vaticano II busca ler os "sinais dos tempos" para entender a vontade de Deus para a humanidade e a missão da Igreja nesse mundo (Gaudium et spes). A Igreja sente a necessidade de mudanças a partir das exigências que o mundo apresenta para a missão evangelizadora contextualizada.

O atual diálogo entre as igrejas afirma que "entre as posiçôes do Vaticano II nas quais se reconhecem preocupações manifestadas por Lutero, podemos mencionar": o apreço à Bíblia (DV), a compreensão da Igreja como Povo de Deus (Cap. II da LG), a necessidade de renovação contínua na Igreja (LG 8; UR 6), a confissão do valor da cruz de Jesus para a comunidade e para cada cristão (LG 8; UR 4; GS 37); a concepção

\footnotetext{
${ }^{28}$ Alberigo, "Il Vaticano II e la riforma della chiesa", 94.

${ }^{29}$ Ibid., 95.
} 
dos ministérios como serviço (CD 16; PO), o sacerdócio comum dos fiéis (LG 10-11; AA 2-4), o direito de cada pessoa à liberdade em questão religiosa $(\mathrm{DH}) .^{30}$

Evidentemente, não basta constatar convergências. A contribuição delas para o fortalecimento dos esforços em busca da unidade entre cristãos católicos e evangélicos depende da forma como as igrejas desenvolvem, juntas, as convicções comuns constatadas. Para isso, urge abandonar o isolamento na formação dos fiéis, na organização das comunidades, na ação evangelizadora, na espiritualidade, para que cada vez mais os elementos comuns verificados possam, de fato, contribuir para que vivamos "Todos sob um mesmo Cristo." 31

\section{Caminhos para a superação das divisões}

\section{Repensando as identidades}

As igrejas sentem as suas identidades ameaçadas pelas mudanças sócio-religiosas da sociedade. Nesse contexto fala-se de crise de identidade eclesial. Frente a isso, há quem procure defender a identidade por um processo de retorno aos usos e costumes da tradição passada que, não raro, desemboca no confessionalismo, no denominacionalismo e no institucionalismo, que são uma espécie de perversão da identidade originária. E há quem proponha repensar a identidade cristã e eclesial num contexto relacional, dialógico, ecumênico.

Este segundo passo mostra que a identidade se constrói num esforço para integrar-se num conjunto maior, onde "o recíproco reconhecimento é um elemento necessário na construção de uma identidade”. ${ }^{32}$

Em geral, as comunidades cristâs associam identidade confessional e identidade eclesial. Elas entendem-se igrejas pelo que e como confessam a fé cristã. Dessa forma se estabelece o perfil de cada igreja, a sua especificidade doutrinal, espiritual e pastoral. A questão ecumênica está no fato de que as igrejas concebem de forma diferente o que é constitutivo da identidade cristā, na confissão individual da fé em Jesus Cristo como Deus, Senhor e Salvador; e, consequentemente, o que é constitutivo da identidade eclesial, na profissão comunitária da fé. Cada igreja vive da convicção de ser a Igreja de

\footnotetext{
${ }^{30}$ Comissão Internacional Católica-Luterana, "Martin Lutero, testimone di Gesù Cristo” No. 24.

${ }^{31}$ Idem, "Tutti sotto uno stesso Cristo", 693-701.

${ }^{32}$ Grupo de Dombes, "Per la conversione delle chiese" No. 12.
} 
Jesus Cristo. Mas "nenhuma igreja confessional pode identificar-se pura e simplesmente com a Igreja de Jesus Cristo". ${ }^{33}$

O problema ecumênico é a cristalização histórica das identidades confessionais, que produz tensões e rupturas na forma de confessar a fé cristã. A defesa das identidades eclesiais é legitima, naturalmente, mas tem gerado feridas nas identidades confessional e cristã que as enrijece numa postura eclesiocêntrica de auto-justificação excludente. A confessionalidade torna-se, assim, confessionalismo e a denominação eclesial torna-se denominacionalismo.

O diálogo ecumênico ajuda a entender que "a identidade confessional deve ser identidade cristã” expressando, primeiramente, o Evangelho. ${ }^{34}$ Assim, uma igreja pode-se relacionar com as demais num espírito de parceria na busca da melhor forma de construir e viver a identidade cristá, eclesial e confessional assumida por todos os cristáos.

Nesse sentido, a identidade eclesial torna-se o objetivo do movimento ecumênico, o qual busca fazer com que a igreja se torne plenamente Igreja, isto é, sempre mais católica, no sentido de plenitude, integridade e universalidade na fé. A identidade eclesial deve estar a serviço da identidade cristã.

Para isso é fundamental fazer um discernimento do que é irrenunciável e os sacrifícios necessários para a identidade eclesial. Há sacrifícios possíveis de algo das formas de vida habituais das igrejas que não ferem a consciência cristá: "Não devemos pedir a ninguém que renuncie às próprias convicçóes sobre a verdade eterna, mas todos devem abandonar o que deve ser abandonado, no interesse da unidade e do que se pode desfazer em boa consciencia." 35

Ninguém possui um conhecimento exaustivo da verdade do Evangelho que nada tenha a acrescentar ou a tirar no diálogo com os demais. Muitas vezes “'a parte de verdade irrenunciável' que habita cada igreja corre sempre o risco de ser também o lugar da própria perversão. Somos convidados, portanto, a interrogar-nos sobre o lugar onde, contemporaneamente, se enraízam seja a identidade, seja a tentação de cada igreja". ${ }^{36}$

\footnotetext{
${ }^{33}$ Ibid. No. 23.

${ }^{34}$ Ibid. No. 35.

${ }^{35}$ Conselho Mundial de Igrejas, “Assemlea di Uppsala (1968) - Documenti aggiuntivi” No. 771.

${ }^{36}$ Grupo de Dombes, "Per la conversione delle chiese" No. 195.
} 
O exercício da autoridade em nome de Cristo pode levar ao abuso e à perversão da autoridade; e a exaltação do carisma da liberdade cristá pode levar à perversão da liberdade.

Exemplo disso é a linguagem da fé. A linguagem pode tornar-se um instrumento inadequado para a recíproca comunicação das convicções das igrejas. Por vezes, certos acentos tornam-se vínculos restritivos dos quais não é fácil libertar a vida eclesial. Não se busca uniformismo lingüístico, mas uma diversidade que expresse a riqueza do Evangelho e não obstaculize a mútua compreensão. É o que se constata nos resultados de alguns diálogos bilaterais nos quais o consenso na fé se expressa na linguagem de cada igreja, como nos acordos sobre cristologia entre Roma e as igrejas do Oriente ${ }^{37}$, e o "consenso diferenciado" na doutrina da justificação entre Roma e a Federação Luterana Mundial (1999). ${ }^{38}$

Evitam-se as expressôes litigiosas, exprimindo a fé em uma nova forma. A Igreja precisa anunciar sua verdade em termos sempre novos, continuamente revendo as expressóes elaboradas no curso da história. $\mathrm{O}$ critério para essa revisão é o conteúdo do Evangelho, que não muda pelas circunstâncias. É, então, necessária uma recíproca interpretação das igrejas que expressem consensos na compreensão e vivência do Evangelho que fundamenta a identidade cristã e eclesial.

\section{Possibilitando a cura da memoria}

Os conflitos históricos entre as igrejas deixaram profundas feridas na memória dos cristãos. Em nossos dias, essas feridas encontram-se ainda expostas nas tradiçóes eclesiais, dificultam a aproximação e causam novas tensóes, preconceitos e hostilidades. O diálogo para o entendimento mútuo exige a cura da memória, o que comporta muitos aspectos, como:

1. Espírito de conversão: A vida cristã é um constante reconhecimento dos próprios limites, erros e pecados, da necessidade de pedir e dar o perdão, de opção por superar tudo o que impede a convivência fraterna. O papa João Paulo II escreveu: "A unidade dos cristãos é possível com a condição de estarmos humildemente conscientes de ter pecado contra a unidade, e convencidos da necessidade da nossa conversáo” (UUS 34).

\footnotetext{
${ }^{37}$ Diálogo Católico-Ortodoxos Orientais (não calcedonenses), "Rapporto della prima Sessione Plenaria", 1056-1063; Comissão Católica-Síria-ortodoxa Malankarese, "Accordo dottrinale cristológico", 588-589.

${ }^{38}$ Comissão Internacional Católica-Luterana, "Consenso sulla dottrina della giustificazione - Dichiarazione ufficiale comune (1999)”, 913-921.
} 
2. A revisão da história cristã, no período anterior à divisão, no contexto da separação e no período posterior. Isso possibilita uma melhor compreensão da mentalidade, das condições e das dinâmicas dos acontecimentos passados, orientando as igrejas para as relaçóes no presente.

3. Reconhecimento do que há em comum no presente e traçar o caminho futuro: por 10 séculos, orientais e ocidentais viveram uma história de fé comum, com fundamento nas Escrituras, na patrística e nas definiçóes doutrinais dos concílios. Essa comunhão foi vivida durante 15 séculos também no Ocidente. $\mathrm{E}$ ainda hoje as igrejas têm em comum muito da fé apostólica que partilharam nesse período, como: a fé nas escrituras como Palavra de Deus; a fé em Deus uno e trino como explicitado no Credo apostólico e niceno-constantinopolitano; o batismo comum; convergências sobre a eucaristia. ${ }^{39}$

Os elementos da fé comum oferecem às igrejas um fundamento teológico do caminho a ser percorrido para se alcançar a plena comunhão no futuro. Com base a eles, o diálogo ecumênico pode ser intensificado possibilitando o intercâmbio de experiências e cooperação em muitas áreas da vida das igrejas.

\section{Redimensionamento estrutural na Igreja}

A reconciliação das igrejas deve ser também estrutural. Mudanças na organização eclesial se fazem necessárias para possibilitar a acolhida mútua, a cooperação, a comunhão dos cristãos. Entre os elementos estruturais que exigem revisão, destacam-se:

- Os ministérios: A Igreja toda é ministerial, sendo todos os cristãos batizados membros de um povo sacerdotal. Mas junto ao sacerdócio comum dos fiéis há também um outro ministério, ordenado, com uma responsabilidade particular na pregação da Palavra, administração dos sacramentos e coordenação da comunidade eclesial. Quem o exerce participa do sacerdócio comum dos fiéis, "mas seu ministério não é uma simples extensão do sacerdócio comum, e sim pertence a uma outra categoria de dons do Espírito" ${ }^{40}$, tal como se expressa pela imposição das mãos no rito de ordenação.

\footnotetext{
${ }^{39}$ Há, ainda, uma compreensão comum da Igreja em sentido amplo, sobretudo nas concepçôes bíblicas de "povo de Deus", "corpo de Cristo" e "templo do Espírito Santo" - mas também na igreja entendida como congregação dos santos, comunhão e suas notas una, santa, católica e apostólica, com diferentes entendimentos sobretudo sobre os elementos da unidade e sobre a apostolicidade. Importantes consensos se manifestam também sobre o lugar da igreja na história da salvaçáo bem como a sua finalidade evangelizadora e a sua contribuiçáo para um mundo de justiça e de paz, bem como na compreensão de muitos dos desafios que a sociedade atual apresenta para a missão da igreja.
}

${ }^{40}$ Comissão Internacional Católica-Anglicana, "Ministero e ordinazione" No. 13. 
Há várias questôes abertas: a estrutura do ministério ordenado, o sujeito - apenas o homem ou também a mulher?, a sacramentalidade, a temporalidade, a sucessão apostólica. A possibilidade do mútuo reconhecimento dos ministérios está estagnada, sobretudo depois que algumas igrejas passaram a ordenar mulheres. Mas é urgente avançar no diálogo sobre essas questóes para dar à Igreja uma estrutura ministerial reconhecida por todos.

- $\quad$ A autoridade na Igreja: outra questão importante na estrutura eclesial é entender quem tem autoridade na Igreja para garantir o testemunho da fé apostólica, como é interpretada e exercida a autoridade magisterial na Igreja, quais são as instâncias competentes para dar em seu nome um juízo oficial sobre consensos na fé. Aqui está em questão o ministério de supervisão (episkopé) dos pastores sobre uma região, bem como o ministério petrino na Igreja universal.

As igrejas se desencontram: na tradição católica a autoridade é exercida pelos bispos das igrejas locais em comunhão com o bispo de Roma, com a primazia deste; os ortodoxos entendem a autoridade de forma sinodal; também para a tradição luterana, o consenso na fé se expressa por uma articulação sinodal formada por bispos (pastores sinodais), pastores e leigos. Outras tradiçóes eclesiais, como a anglicana, aproximam-se dos luteranos, envolvendo na tomada de decisões a câmara dos bispos, dos presbíteros e dos leigos, em pé de igualdade. Essas autoridades exercem o ensino da fé podendo formular declarações doutrinais conforme a necessidade.

¿A questáo é complexa, e nela o ministério petrino recebe uma atenção especial no diálogo ecumênico. O debate concentra-se na concepção da jurisdição universal do bispo de Roma e no seu ensino infalível sobre fé e moral, que encontra sérias resistências nas demais igrejas. Estas entendem "ter o direito de receber garantias que o reconhecimento do primado universal do bispo de Roma náo implica a supressão das tradiçôes teológicas, litúrgicas e das outras tradições às quais atribuem valor ou a imposição de tradições totalmente estranhas". ${ }^{41}$

O papa João Paulo II reconheceu: "o ministério do bispo de Roma [...] constitui uma dificuldade para a maior parte dos outros cristáos, cuja memória está marcada por certas recordaçôes dolorosas" (UUS 88). É verdade que o atual pontificado do papa Francisco tem recebido significativas manifestações de acolhida por parte das igrejas, tanto pelo seu estilo franco na abertura ao diálogo, à convivência e à cooperação; como pela sua humildade em relaçáo à verdade, afirmando que "não se deve esperar do magistério papal uma palavra definitiva ou completa sobre todas as questóes que dizem respeito à Igreja e ao mundo" (EG 16).

${ }^{41}$ Idem, “Autorità nella chiesa II” No. 22. 
Mas o papa Francisco não apresenta, ainda, possibilidades de alteraçóes significativas no governo da Igreja Católica. Mudanças estruturais certamente não acontecerão em um pontificado apenas. $\mathrm{Na}$ verdade, a acolhida que o papa Francisco recebe das demais igrejas diz respeito à sua pessoa, como bispo de Roma, e não propriamente da instituição do papado que ele representa. ${ }^{42} \mathrm{E}$ há que se admitir que sobre o ministério petrino até hoje nem a sua teoria e nem a sua prática foi observada de modo a sempre favorecer a fraternidade entre as igrejas.

Facilita para isso se esse ministério não for entendido apenas em termos jurídicos, mas também teológicos e pastorais, como o Vaticano II o apresenta. Já foi apresentada a proposta de fazer uma justa distinção das funçôes do bispo de Roma: quais dizem respeito à sua diocese; quais são relativas ao seu ofício de patriarca da Igreja latina; e quais são, de fato, essência do seu ministério universal a serviço da unidade. Essas distinçôes podem favorecer a compreensão desse ministério como útil a todos os cristãos:

Se hoje se reconhecesse claramente este ponto, seria mais fácil para os metodistas reconsiderar sua posição e perguntar-se se o bispo de Roma não possa exercitar também para outros cristãos esse ministério que ele exercita para aqueles que já o aceitam. ${ }^{43}$

Seja como for, sobre a difícil e complexa questão da autoridade, muitos cristãos "reconhecem juntos a realidade da episkopé (supervisão) no Novo Testamento e são de acordo sobre o fato que um ministro ordenado que exercite a episkopé tem uma importância vital para a existência da Igreja”. ${ }^{44}$

Cabe chegar à compreensão sobre como esse ministério pode ser realizado de forma diversa nas diferentes tradiçóes eclesiais, expressando a pluralidade legítima na organização da Igreja, sem ferir a sua unidade, catolicidade e apostolicidade: “...a Igreja tem necessidade de uma autoridade múltipla e difusa, na qual todo o povo de Deus esteja ativamente envolvido, e também de um primado universal como servidor e centro de unidade visível na verdade e no amor." ${ }^{45} \mathrm{O}$ fundamental é entender que ele é um elemento essencial para a koinonia no testemunho do Evangelho.

\footnotetext{
${ }^{42}$ Uma análise do pontificado de Francisco em perspectiva de reforma na igreja católica, pode ser vista em Wolff, "Reformas na igreja: chegou a vez do catolicismo? Uma aproximação dos 50 anos do Vaticano II e os 500 anos da Reforma Luterana, no contexto do pontificado do papa Francisco", 534-567.

${ }^{43}$ Comissão Internacional Católica-Metodista, "Verso uma dichiarazione sulla Chiesa" No. 59.

${ }^{44}$ Idem, "La tradizione apostólica - 1991” No. 92; Comissão Internacional Católica-Anglicana, "Autorità nella chiesa I" No. 5.

${ }^{45}$ Ibid. II No.33.
} 


\section{Conclusão}

Avanços no diálogo doutrinal permitem hoje as igrejas afirmarem juntas, mesmo se com linguagens próprias, elementos centrais da fé cristã relativos aos sacramentos, às estruturas eclesiásticas, ao vínculo entre escrituras e tradição, à espiritualidade cristá, à missão, etc. Persistem ainda divergências doutrinais entre as igrejas, mas há o reconhecimento de um patrimônio comum, ainda que esse patrimônio tenha expressóes diferentes nas teologias de cada tradição eclesial.

Esse fato exige verificar se o que hoje une os cristãos é mais forte do que o que os separa. Se a resposta for positiva, já não mais se sustenta a manutenção de todos os fatores de divisão manifestados em contendas teológicas do passado. Para isso, é preciso admitir que nem sempre se compreendeu de fato o que o outro quis dizer. $\mathrm{O}$ estudo atual da intenção dos envolvidos nas querelas teológicas de então, não raro constata consensos onde tudo parecia contradição. A intenção que o outro expressava da fé não era errada ou herética em sua totalidade.

A fé cristã não é cancelada apenas pelo fato de ser afirmada por proposiçôes teológicas diferentes das convencionadas. E nesse caso, coloca-se em questão se há realmente o objetivo de dividir a Igreja ou, ao contrário, ao questioná-la o que se quer é contribuir para que aconteçam as mudanças necessárias para que ela se mantenha mais fiel às suas origens em Cristo.

Não basta o trabalho dos teólogos para a revisão da situação de divisão dos cristãos em perspectiva reconciliadora. É preciso que também as hierarquias eclesiásticas se disponham a fazê-lo. O teólogo pode ajudar suas lideranças no entendimento da complexidade das razóes que levaram à divisão dos cristãos no passado, do status quaestionis da divisão no presente, dos passos dados para a reaproximação, do caminho que resta a seguir. Uma vez esclarecidos nesses pontos, entre outros, os líderes das igrejas devem tomar a iniciativa de realizar atos oficiais de reconciliação.

Anseia-se que isso aconteça num futuro breve, em contexto celebrativo, de caráter penitencial pelos erros de uns e de outros. A reconciliaçáo acontece por etapas, gradualmente, até se restabelecer a comunhão plena. Trata-se de uma ação de graças e de louvor a Deus pela coragem profética das igrejas de retirarem de seu meio as forças divisionistas que outrora se impuseram. Isso não é ficção teológica, mas parresia da fé cristã e evangélica, com um significado eclesial profundo que penetra na vida dos discípulos de Cristo que ouvem a voz do Mestre: "que sejam um”! 


\section{Referências}

Alberigo, Giuseppe. "Il Vaticano II e la riforma della chiesa." In Ecumenismo, Anni 80, SAE, 93-103. Verona : Il Segno Editrice, 1984.

Antón, Angel. El misterio de la Iglesia. Vol. 2. Madrid: Biblioteca de Autores Cristianos, 1986.

Bouyer, Louis. Newman. His Life and Spirituality. London: Burns \& Oaetes, 1958.

Comissão Católica-Síria-ortodoxa Malankarese. "Accordo dottrinale cristológico." Il Regno (Documenti) 35 (1990): 588-589.

Comissão Internacional Católica-Anglicana. “Autorità nella chiesa II.” In Echiridion Oecumenicum I, 69-85. Bolonha: EDB, 1986.

. "Ministero e ordinazione." In Echiridion Oecumenicum I, 6-35. Bolonha: EDB, 1986.

Comissão Internacional Católica-Luterana. "Consenso sulla dottrina della giustificazione - Dichiarazione ufficiale comune (1999).” In Echiridion Oecumenicum VII, 913-921. Bolonha: EDB, 2006.

. "L'unità davanti a noi." In Enchiridion Oecumenicum, I, 752-823. Bolonha: EDB, 1986.

. "Martin Lutero, testimone di Gesù Cristo." In Echiridion Oecumenicum I, 743-751. Bolonha: EDB, 1986.

. "Tutti sotto uno stesso Cristo." In Echiridion Oecumenicum I, 693-701. Bolonha: EDB, 1986.

Comissão Internacional Católica-Metodista. “La tradizione apostólica - 1991.” In Echiridion Oecumenicum III, 770. Bolonha: EDB, 1995.

. "Verso uma dichiarazione sulla Chiesa." In Echiridion Oecumenicum III, 711-738. Bolonha: EDB, 1995.

Congar, Yves. Chétiens désunis. Paris: Edition du Cerf, 1937.

. Esquisses du mystère de l'Église. Paris: Edition du Cerf, 1941.

. Vrai et fausse réforme dans l'Église. Paris: Editions du Cerf, 1950.

Conselho Mundial de Igrejas. "Assemblea di Amsterdam (1948). Rapporti delle sezioni.” In Enchiridion Oecumenicum V, 4-85. Bolonha: EDB, 2001. . "Assemblea di Evaston (1954) - Rapporti delle sezioni." In Enchiridion Oecumenicum V, 89-198. Bolonha: EDB, 2001. 
. "Assemblea di Uppsala (1968) - Documenti aggiuntivi." In Enchiridion Oecumenicum V, 342-586. Bolonha: EDB, 2001.

Cullmann, Oscar. "Conferência em São Luís dos Franceses, em dia 02 de dezembro, durante a 2a . sessão do Concílio, falando sobre a "história da salvação no Novo Testamento." In O Diário do Concílio, Henri Fesquet. Vol. I. Men Martins, Sintra: Publicações Europa-América, 1967.

De Lubac, Henri. Catholicisme. Les aspesctes sociaus du dogme. Paris: Edition Du Cerf, 1938.

Diálogo Católico-Ortodoxos Orientais (não calcedonenses). "Rapporto della prima Sessione Plenaria." Enchiridion Oecumenicum 1, Bolonha: EDB, 1986, pg. 1053-1063.

Fé e Constituição. "I Conferência Mundial - Lausanne, 1927." In Enchiridion Oecumenicum VI, 5-437. Bolonha: EDB, 2005.

Grupo de Dombes. "Per la conversione delle chiese." In Enchiridion Oecumenicum, IV, 306-399. Bolonha: EDB, 1999.

João Paulo II. "Discurso à Federação das Igrejas protestantes da Suíça (junho de 1984).” Vatican, http://w2.vatican.va/content/john-paul-ii/it/speeches/1984/ june/documents/hf_jp-ii_spe_19840614_chiese-protestanti.html (acesso em 20 de julho de 2014).

Kasper, Walter. Chiesa Cattolica - Essenza, realtà, missione. Brescia: Queriniana, 2012.

Kloppenburg, Boaventura. Concílio Vaticano II. Vol. III. Segunda Sessão. Rio de Janeiro: Vozes, 1964.

. Concílio Vaticano II. Vol. IV. Terceira Sessäo. Rio de Janeiro: Vozes, 1964.

Lutero, M. "Artigos de Esmalcalde - A Igreja." In Confessioni di fede delle Chiese Cristiane, org. Romeo Fabri, 329-360. Bolonha: EDB, 1996.

Möhler, John Adam. L'unità nella Chiesa. Il principio del cattolicesimo nello spirito dei Padri della Chiesa dei primi tre secoli. Roma: Città Nuova, 1969.

Ruggieri, G. (org). Alle radici della divisione - Una rilettura dei grandi scismi storici. Milano: Ancora, 2000.

Tuchle, G. Nova história da Igreja - A Reforma e Contra-Reforma. Vol. III. Rio de Janeiro: Vozes, 1971.

Vonier, Anscar. The People of God. Londres: Assumption Press, 1937. 
Walgrave, J.-H. "La croissance spirituelle de Newman et l'idée du développement." In Newman, le développement du dogme, por J.-H. Walgrave, 36-52. Paris: Tournai, 1957.

Wolff, Elias. "Reformas na igreja: chegou a vez do catolicismo? Uma aproximação dos 50 anos do Vaticano II e os 500 anos da Reforma Luterana, no contexto do pontificado do papa Francisco." Revista Horizonte 12, No. 34 (2014): 534-567. 
